\title{
Effect of processing on proximate and mineral composition of black climbing (P. coccineus L.) bean flour
}

\author{
Mengistu Tadesse Mosisa \\ Department of Chemical Engineering, School of Mechanical Chemical and Material Engineering, Adama Science and \\ Technology University, Adama-Ethiopia.
}

Received 15 June 2016 Accepted 19 October, 2016

\begin{abstract}
The objective of this study was to determine the effect processing on proximate and mineral compositions of raw and processed seeds of black climbing bean "hepho" (Phaseolus coccineus L.). The experiment was conducted on raw, dehulled and undehulled black climbing bean flour. The processing techniques employed were traditional (TC) and pressure cooking (PC), while the raw sample served as control. The processing techniques showed deviations in nutrient content from the raw by the all tested processing techniques particularly, PC which caused a significantly $(p<0.05)$ difference in all the proximate contents except the carbohydrate content, whereas TC showed a significant $(p<$ 0.05) difference in only some of the proximate composition. Generally, both the traditional cooking (DTC and UTC) and pressure cooking (DPC and UPC) techniques caused significant difference ( $p$ $0.05)$ in some of the mineral profile of hepho ( $\mathrm{Ca}, \mathrm{P}$ and $\mathrm{Fe})$ except the zinc content which has nonsignificant $(p>0.05)$ difference. Although all the process technique applied in this study have significant effect in the composition of hepho bean contents; DPC and UPC which have the most suitable techniques to prevent the loss of protein and minerals ( $\mathrm{Ca}, \mathrm{P}, \mathrm{Fe}$ and $\mathrm{Zn}$ ). Hence, the black climbing bean seeds "hepho" is an alternative and cheaper source of protein and contribute to solve the problem of malnutrition which is a prevalent problem in developing world especially, Ethiopia.
\end{abstract}

Key words: "Hepho" (Phaseolus coccineus L.) traditional cooking, pressure cooking, chemical composition.

\section{INTRODUCTION}

Protein-calorie deficiency is now viewed as the major nutritional problem in most developing countries including Ethiopia. Due to the high price of animal proteins, much importance is now placed on plant foods as a source of proteins in all developing countries (Yagoub et al., 2008). The dearth in food supply especially of protein is so enormous that, the developing nations have to depend on cereals, grains, starch roots and tubers for energy and protein need (Akporhonor et al., 2006; Aremu et al., 2009). Legumes which refer to the seeds of Leguminosae include: peas, beans and pulses. Legumes are considered as "poor man's meat" due to their high protein

E-mail: mengistutadese706@gmail.com.

Author(s) agree that this article remains permanently open access under the terms of the Creative Commons Attribution License 4.0 International License 
content and low cost sources (Aremu et al., 2006a). The bean to be used as food, is better to have proximate contents (Derese, 2012) which comprises of 15 to $25 \%$ proteins, 50 to $75 \%$ carbohydrates mostly starch and about 1 to $3 \%$ fat, 2.9 to $4.2 \%$ ash and 3.5 to $6.5 \%$ crude fiber. Further, beans contain considerable amounts of vitamins, minerals and nutritionally useful quantities of many essential amino acids (Vidal-Valverde et al., 1993; Oshodi et al., 1998).Though legumes are important sources of dietary proteins for human and animals, their usefulness have been hindered by the presence of some anti-nutritional factors known as toxins (Onyeike et al., 1995; Aremu et al., 2010).

Nutritional quality is affected by these factors that interact with the intestinal tract such as phytate, tannins and oxalates which reduce protein digestibility and amino acid absorption (Nowacki, 1980; Davis, 1981). However, these substances need to be destroyed either by heat or other treatments otherwise concentration of toxins will exert adverse physiological effects when ingested by man and animals (Liener, 1994). Hepho is the Afan Oromo name for black climbing bean (Phaseolus coccicneus $\mathrm{L}$.) which is a seed pulse crop, belongs to the Phaseolus species and family of Leguminosae (Zelalem, 2002). Therefore, the word hepho, as used by the Oromo, which describes the entire black climbing bean with black seed bean. Hepho bean (Phaseolus coccineus L.) is one of the principal food and cash crops legumes grown in both the lowland and medium altitude areas of Ethiopia ranging from 700 to $2000 \mathrm{~m}$ above sea level and this crop has been known in the country since the $16^{\text {th }}$ century (Shimelis and Rakshit, 2005). Hepho is well known in the North-West parts and Wollega Zones (Western and Eastern Wollega Zones of Oromia region and Bennishangul-Gumuz region in Ethiopia (Derese, 2012). Cranberry bean (Phaseolus coccineus L.) are low in fat and loaded with nutrients, and one would probably love to eat more of them if they were not also loaded with flatulence-producing enzymes (Denonck, 1991).

The growth habit of hepho is use in determining type-4 (climbing), seeds size is medium spexled /speckled with black color. Intercropping with maize is planted under Fence around household (supportive) (Aremu et al., 2010). Hepho seed usually reach a harvestable stage within five to six months from planning depending on the environment, the plant dies after the seeds have matured (Tadese and Bekele, 2003). Although relevant literature on chemical compositions of processed $P$. coccineus is not widely available, recent studies have shown that the mature seeds are of good source of essential minerals and amino acids (Aremu et al., 2005, 2008). It has not gained widespread industrial, economic and nutritional importance because its acceptability and utilization have been limited. Black climbing (Hepho) bean is an excellent source of vegetable protein, starch, soluble and insoluble fiber, vitamins (especially B group) and elements (particularly potassium, iron, zinc, magnesium, phosphorus and manganese).

Results of these contents black climbing is consumed in different forms; such as 'Wett', which is prepared from the bean (both dehulled and undehulled) with addition of salts, pepper and butter and 'Nifero', that is prepared from the hepho bean with addition of maize. Form these consumption forms of "Hepho" or black climbing bean which is obtained directly or indirectly through heating operation of processing methods such as cooking and dehulling, it can effectively reduce the antinutritionl factors and improve the nutritional value of the beans that are applied on it. The industrial and nutritional potential of this crop is unknown to the host communities. Therefore, this study was aimed to evaluate the effect of different processing techniques on proximate and elemental compositions of black climbing bean "hepho" (Phaseolus coccineus L.); with a view of providing preliminary information towards effective utilization of this legume in various food dishes, to fight protein energy malnutrition.

\section{MATERIALS AND METHODS}

\section{Collection of Sample}

For the purpose of this study, mature seeds of Hepho beans (Phaseolus coccineus L.) were collected randomly from 18 selected households ( 1 kilogram per house hold) of study site (Bandira, Kubena Hambelta and Horo Hambelta kebeles), Ethiopia. The seeds were thoroughly cleaned and sorted to remove stones and bad ones. The samples were packed in polyethylene bags, kept in an ice-box (to prevent moisture loss), and transported to Food Technology and Process Engineering laboratory of Wollega University and Ethiopian Health and Nutrition Research Institute (EHNRI), Ethiopia, within the same day.

\section{Preparation of processed hepho bean seeds}

The experiment was conducted on raw, dehulled and undehulled hepho bean seed. The processing techniques employed were traditional and pressure cooking, while raw sample was served as control.

\section{Cooked seeds}

\section{Traditional cooking}

The seeds were soaked in water in the ratio (1:10) (wt/vol) and was taken for cooking. The ordinary cooking was done by using local cooking pot for 1 and $2 \mathrm{~h}$, respectively (dehulled and undehulled hephoo bean) until they became soft when felt between the fingers following the method justified by the local women. The cooking water was drained off and the seeds were sun dried for two days and ground into fine powder by using an electric mill (NIMA-8300 Burman, Germany) until to pass through $0.425 \mathrm{~mm}$ sieve mesh size. Samples were preserved in air-tight bottles in the refrigerator for analysis.

\section{Pressure cooking}

The dehulled and undehulled seeds of Hepho were pressure cooked in house hold pressure cooker at $101.31 \mathrm{Kpa} \mathrm{(15} \mathrm{psi}$ 
Table 1. Proximate composition (g/100 g dry weight) of raw and processed Hepho bean seeds (Phaseolus coccineus L.).

\begin{tabular}{|c|c|c|c|c|c|c|c|}
\hline Treatment & Moisture & protein & fat & fibre & $\mathrm{CHO}$ & energy & Ash \\
\hline Raw & $7.14 \pm 0.03^{\mathrm{a}}$ & $24.63 \pm 0.23^{b}$ & $0.90 \pm 0.03^{\mathrm{ba}}$ & $4.63 \pm 0.02^{\mathrm{a}}$ & $65.85 \pm 0.36^{\mathrm{bc}}$ & $369.89 \pm 0.26^{\mathrm{cb}}$ & $3.99 \pm 0.09^{b}$ \\
\hline DTC & $\begin{array}{c}7.13 \pm 0.03^{\mathrm{a}} \\
(-0.1 \%)\end{array}$ & $\begin{array}{c}28.16 \pm 0.04^{\mathrm{a}} \\
(+14 \%)\end{array}$ & $\begin{array}{c}0.83 \pm 0.04^{b} \\
(-8 \%)\end{array}$ & $\begin{array}{c}4.11 \pm 0.02^{\mathrm{dc}} \\
(-11 \%)\end{array}$ & $\begin{array}{c}64.29 \pm 1.43^{d} \\
(-2 \%)\end{array}$ & $\begin{array}{c}378.24 \pm 12.78^{\mathrm{a}} \\
(+2 \%)\end{array}$ & $\begin{array}{c}2.61+0.07^{d} \\
(-35 \%)\end{array}$ \\
\hline UTC & $\begin{array}{c}7.37 \pm 0.03^{\mathrm{a}} \\
(+3 \%)\end{array}$ & $\begin{array}{c}24.67 \pm 0.24^{b} \\
(+0.16 \%)\end{array}$ & $\begin{array}{c}0.92 \pm 0.00^{\mathrm{a}} \\
(+2 \%)\end{array}$ & $\begin{array}{c}4.06 \pm 0.07^{d} \\
(-12 \%)\end{array}$ & $\begin{array}{c}67.22 \pm 0.23^{\mathrm{a}} \\
(+2 \%)\end{array}$ & $\begin{array}{c}375.82 \pm 0.12^{\mathrm{a}} \\
(+2 \%)\end{array}$ & $\begin{array}{c}3.14 \pm 0.31^{\mathrm{c}} \\
(-21 \%)\end{array}$ \\
\hline DPC & $\begin{array}{c}8.67 \pm 0.13^{\mathrm{a}} \\
(+21 \%)\end{array}$ & $\begin{array}{c}24.68 \pm 0.10^{b} \\
(+0.20 \%)\end{array}$ & $\begin{array}{c}0.97 \pm 0.10^{\mathrm{a}} \\
(+8 \%)\end{array}$ & $\begin{array}{c}4.13 \pm 0.22^{\mathrm{c}} \\
(-11 \%)\end{array}$ & $\begin{array}{c}65.12 \pm 0.17^{\mathrm{dc}} \\
(-1 \%)\end{array}$ & $\begin{array}{c}367.87 \pm 0.45^{\mathrm{c}} \\
(-1 \%)\end{array}$ & $\begin{array}{c}4.31 \pm 0.04^{\mathrm{a}} \\
(+8 \%)\end{array}$ \\
\hline UPC & $\begin{array}{c}8.24 \pm 0.03^{a} \\
(+15 \%)\end{array}$ & $\begin{array}{c}24.46 \pm 0.42^{b} \\
(-0.69 \%)\end{array}$ & $\begin{array}{c}0.91 \pm 0.02^{\mathrm{ba}} \\
(+1 \%)\end{array}$ & $\begin{array}{c}4.44 \pm 0.84^{b} \\
(-4 \%)\end{array}$ & $\begin{array}{c}66.57 \pm 0.04^{\mathrm{ba}} \\
(+1 \%)\end{array}$ & $\begin{array}{c}372.23 \pm 0.24^{\mathrm{b}} \\
(+1 \%)\end{array}$ & $\begin{array}{c}3.99 \pm 0.20^{\mathrm{b}} \\
(0 \%)\end{array}$ \\
\hline
\end{tabular}

Each value represents the mean \pm standard deviation of three triplicate determinations. Carbohydrate $\%$ calculated as the (100-total of other components). Energy $\%$ calculated $\mathrm{kJ} / 100 \mathrm{~g}$ (protein $\times 17+$ fat $\times 37+\mathrm{CHO} \times 17$ ). NB: DTC stands for De-hulled Traditionally Cooked, UTC for Undehulled Traditionally Cooked, DPC for Dehulled Pressure Cooked, and UPC for Undehulled Pressure Cooked." " $(+)$ and $(-)$ indicate increased and decreased from raw mean" Means in the same column with different superscript letters are significantly $(p<0.05)$ different.

pressure), $121^{\circ} \mathrm{C}$ in tap water $(1: 10, \mathrm{w} / \mathrm{v})$ for $14 \mathrm{~min}$. The cooking water was drained off and the seeds were sun dried for two days, ground into fine powder by using an electric mill (NIMA-8300 Burman, Germany) until it pass through $0.425 \mathrm{~mm}$ sieve mesh size. Samples were preserved in air-tight bottles in the refrigerator for analysis.

\section{Experimental site}

Sample preparation and moisture content determination were conducted in the laboratory of Wollega University; Food Technology and Process Engineering Department, but the other Nutritional composition both proximate and mineral analysis was carried out in Ethiopian Health and Nutrition Research institute laboratory. All determinations were carried out in triplicate.

\section{Procedure of analysis}

\section{Proximate analysis}

The moisture, ash, crude fat, crude fibre, crude protein $(\mathrm{N} \times 6.25)$ and carbohydrate (by difference) were determined in accordance with methods of the Association of, Official Analytical Chemists (2000). All proximate analyses of the legume seeds were carried out in triplicate and reported in percent. All chemicals were of Analytical grade.

\section{Mineral analysis}

Phosphorus was determined by Vanadomolybdate colorimetric method (AACC, 2000). Calcium, iron and zinc were determined by Atomic Absorption Spectrophotometer (Buck Scientific's 210VGP, USA). All determinations were done in triplicate and the minerals were reported in $\mathrm{mg} 100 \mathrm{~g}^{-1}$ sample.

\section{Statistical Analysis}

The results obtained from the various analyses were subjected to
Analysis of Variance (ANOVA) using Statistical Package for Social Sciences (SPSS) version 16.0 (SPSS Inc., Chicago IL, USA).

\section{RESULTS AND DISCUSSIONS}

Table 1 shows the proximate composition of raw and processed Hepho bean seeds. The moisture, crude protein, crude fat, crude fiber, carbohydrates, and ash values were reported in percentage of dry weight.

\section{Moisture}

In all treatment, moisture content was increased except in DTC (Table 1), non-significant differences $(P<0.05)$. The moisture content hepho (black climbing) bean of pressure cooked (PC) and traditional cooking (TC) sample has shown increment from 3.22 to $21.43 \%$ (Table 1). These findings were in agreed with the report of Audu and Aremu, (2011), that the moisture content of red kidney bean has increased $(33.33 \%)$. Generally, the different processing techniques employed in this study increased the moisture content in this order: DTC $<$ UTC $<$ UPC $<$ DPC.

The increased moisture content might be due to water absorption by fibers and other natural chemical components during heat treatment (Ejigui et al., 2005; Mubarak, 2005 and Mittal et al., 2012).

\section{Crude Protein}

Crude protein value of $24.63 \%$ of raw Hepho bean seed (Table 1) is comparable to some commonly beans (Fasoyiro et al., 2006) (Table 2) though lower as compare 
Table 2. Proximate compositions $(\mathrm{g} / 100 \mathrm{~g})$ of some under-utilized grain legumes seed* and black climbing (Hepho) bean**.

\begin{tabular}{lccccc}
\hline Legumes & Protein & Fat & Carbohydrate & Ash & Fibre \\
\hline Hepho bean & 24.63 & 0.90 & 65.85 & 3.99 & 4.63 \\
Common bean & $20-27$ & $1-2$ & $60-65$ & $4-5$ & $4-5$ \\
Lima bean & $19-25$ & $2-3$ & $50-51$ & $4-6$ & $1-2$ \\
Winged bean & $30-40$ & $15-20$ & $35-45$ & $6-7$ & $3-5$ \\
Cowpea & $22-26$ & $1-2$ & $50-60$ & $3-4$ & $3-4$ \\
Soybean & $33-41$ & $17-18$ & 25.30 & $4-6$ & $4-5$ \\
Hyacinth bean & $24-28$ & $1-2$ & $65-70$ & $7-9$ & $4-5$ \\
Pigeon pea & $17-26$ & $1.9-2.8$ & $48-49$ & $3-4$ & $4-6$ \\
\hline
\end{tabular}

* Source: Fasoyiro et al. (2006). ** Laboratory analysis of black climbing (hepho) bean.

to the results of selected beans such as winged bean 30 to $40 \%$, soybean 37 to $41 \%$ and pigeon pea 28 to $29 \%$. The mean crude protein content for dehulled traditionally cooked (DTC) was significantly $(p<0.05)$ higher, but there was non- significant difference $(p<0.05)$ in the crude protein content for UTC, PC and UPC as compared to the raw seeds. The different processing techniques enhanced crude protein content of Hepho bean in this order: UTC < DPC < DTC (Table 1). UTC increased the crude protein content of the dehulled $P$. coccineus seed by $14 \%$.

\section{Crude Fat}

The UTC and UPC seeds increased in crude fat content (Table1). This result was in agreement with Akajayeju and Ajayi (2011), that cooking enhanced crude fat in African oil bean. DTC decreased the crude fat content by $7.78 \%$. The reduction in crude fat content in the cooked seeds may be due to leaching, while reduction in sprouted seed may be due to metabolic activity taking place in the seeds (Kylen and McCready, 1975).

\section{Crude Fiber}

Crude fibre content of $4.63 \%$ of raw Hepho bean seed is within the expected values of most beans (Table 2). The mean crude fiber content of DTC, UTC, DPC and UPC hepho bean seeds were significantly $(p>0.05)$ different when compared with crude fiber content of raw and UPC hepho bean seed.

Similarly, the DPC has significant $(p<0.05)$ different in compared to DTC and UTC. The mean crude fiber content of UPC has non -significant $(p>0.05)$ different in compared to DPC mean fiber content of hepho bean seeds (Abiodum and Adepeju, 2011). In DTC, UTC and UPC processing techniques, the crude fibre content decreased and increased in DPC (Mubarak, 2005). This suggests that the sample would provide moderate dietary fibre in the diet. Fibre helps to maintain the health of the gastrointestinal tract, but in excess may bind trace elements, leading to deficiencies of iron and zinc (Siddhuraju et al., 1996).

\section{Carbohydrate}

The mean total carbohydrate content of DTC, UTC, DPC and UPC Hepho bean seeds were presented in Table 1. Changes in total carbohydrate values of both raw and processed hepho bean seeds reflect change in observed values of other proximate composition. The values of mean total carbohydrate for traditionally cooked has significant $(p<0.05)$ different, when compared with raw hepho bean seeds, while, pressure cooked samples showed non-significant $(p<0.05)$ difference in comparison with raw sample (Table 1 ). The result has shown that Hepho bean seed contained higher amount of carbohydrate as other dry beans and this indicate that, hepho bean seeds could be a good source of carbohydrate energy.

The UTC and UPC techniques increased the total carbohydrate content in undehulled seeds while decreased the total carbohydrate content in dehulled seeds (Table 1). This was in agreement with Mugendi et al. (2010), which reported the total carbohydrate content of Jack bean was increased by $24.69 \%$ by pressure cooking and by $19.38 \%$ by convectional cooking. Carbohydrate was calculated by the difference accounted for $65.85 \%$ in the raw Hepho bean seed. The carbohydrate content suggests that the seed could be a good supplement to scarce cereal grains as sources of energy and feed formulations. The carbohydrate value was compares with the range value of 60 to $65 \%$ of common bean and cowpea as reported by Fasoyiro et al. (2006) (Table 2). The value is however higher than those of soya bean (26.3\%) as reported by Temple et al. (1991), cranberry bean (31.5\%), red specks coat and 
Table 3. Mean mineral composition $(\mathrm{mg} / 100 \mathrm{~g} \mathrm{db}$ ) of raw and processed Hepho bean seeds (Phaseolus coccineus L.).

\begin{tabular}{lcccc}
\hline Treatment & Calcium & Phosphorous & Iron & Zinc \\
\hline Raw & $145.21+0.01^{\mathrm{a}}$ & $342.27 \pm 0.02^{\mathrm{a}}$ & $8.20 \pm 0.01^{\mathrm{a}}$ & $1.70 \pm 0.97^{\mathrm{a}}$ \\
DTC & $110.16 \pm 0.02^{\mathrm{b}}$ & $241.91 \pm 0.01^{\mathrm{b}}$ & $7.84_{ \pm} 0.01^{\mathrm{b}}$ & $1.40 \pm 0.01^{\mathrm{b}}$ \\
& $(-24.14 \%)$ & $(-29.32 \%)$ & $(-4.39 \%)$ & $(-17.65 \%)$ \\
& & & & \\
UTC & $122.29 \pm 0.02^{\mathrm{c}}$ & $250.99_{ \pm} 1.41^{\mathrm{c}}$ & $8.01 \pm 0.01^{\mathrm{a}}$ & $1.35_{ \pm} 0.02^{\mathrm{c}}$ \\
& $(-15.78 \%)$ & $(-26.66 \%)$ & $(-0.06 \%)$ & $(-20.58 \%)$ \\
DPC & $137.82 \pm 0.39^{\mathrm{d}}$ & $279.23+0.44^{\mathrm{d}}$ & $8.19 \pm 30^{\mathrm{a}}$ & $1.54 \pm 0.08^{\mathrm{d}}$ \\
& $(-5.08 \%)$ & $(-18.41 \%)$ & $(-0.12 \%)$ & $(-9.41 \%)$ \\
UPC & $139.73 \pm 0.09^{\mathrm{e}}$ & $297.05+0.05^{\mathrm{e}}$ & $8.10 \pm 0.05^{\mathrm{a}}$ & $1.60 \pm 0.32^{\mathrm{e}}$ \\
& $(-3.77 \%)$ & $(-13.21 \%)$ & $(-1.22 \%)$ & $(-5.88 \%)$ \\
\hline
\end{tabular}

"Mean not followed by the same superscript letters in the same column are significantly different $(\mathrm{P}<0.05)$. NB: DTC stands for De-hulled Traditionally Cooked, UTC for Undehulled Traditionally Cooked, DPC for Dehulled Pressure Cooked, and UPC for Undehulled Pressure Cooked." "(+) and (-) indicate increased and decreased from raw mean".

white coat scarlet runner bean, 31.4 and $30.1 \%$, respectively (Aremu et al., 2006b) but lower to those reported for kerstings groundnut $(77.3 \%)$, moderate brown coat cowpea $(82.9 \%)$ and small white coat cowpea (77.2\%) (Aremu et al., 2006a).

\section{Energy}

The energy value (KJ / $100 \mathrm{~g}$ ) was 367.87 in DPC and 378.24 in DTC sample. Changes in energy values of both raw and processed seeds of Hepho bean seed reflect changes in the observed values of other proximate composition (Table 1).

\section{Total ash}

The ash content of $3.99 \%$ (Table 1) observed is moderate but higher than those of the wild jack bean (3.0\%) (Vidivel and Janardhanen, 2001), melon seeds (3.3\%) (Omafuvbe et al., 2004) and Vigna ublobata (3.2\%) (Khalil and Khan, 1995), castor seeds (Ricinus communis) (3.2\%) (Onyeike and Acheru, 2002). Since the sample contained fairly high ash content, it may indicate that the legume could provide essential valuable and useful minerals needed for good body development since soya bean which occupies a unique position among leguminous crops has an average ash content of $4.2 \%$ (Temple et al., 1991). DTC, UTC, DPC and UPC samples were presented in (Table 1). All the processing techniques employed in this study with exception of DPC decreased the total ash content in the order of DTC
= UTC > UPC (Table 1). However, the DPC increased the mean total ash content. In addition to the effect of process, the black climbing bean (Hepho) had high proximate composition in compared to other well- known legumes. This indicates the hepho which had high nutritional value as the other known common beans (Table 2).

The mineral profile of Hepho bean seeds is presented in Table 3. The most abundant mineral in the raw seed was phosphorus $(342.27 \mathrm{mg} / 100 \mathrm{~g})$, calcium (145.21 $\mathrm{mg} / 100 \mathrm{~g}$ ), while the least concentrated ones iswas zinc $(1.70 \mathrm{mg} / 100 \mathrm{~g})$. Processing techniques significantly affected the contents of tested minerals in Hepho bean seed $(P<0.05)$. All the tested processing techniques reduced calcium, phosphorus, iron and zinc.

\section{Calcium}

The different processing techniques employed in this study significantly $(P<0.05)$ reduced the mean calcium content of hepho seed as compared to the raw seed. This result also showed significance $(p<0.05)$ difference in the mean calcium content of hepho bean among each processing methods under the study (Table 3). The mean calcium content of raw hepho bean seeds was found to be $145.21 \mathrm{mg} / 100 \mathrm{~g}$. This was lower than the report of Ejigui et al. (2005), which state that calcium content of red kidney bean is $179.12 \mathrm{mg} / 100 \mathrm{~g}$ but, higher than calcium content of mung bean which was found to be $84.00 \mathrm{mg} / 100 \mathrm{~g}$. The mean Calcium content of DTC, UTC, DPC and UPC were presented in Table 3. All the different processing methods in this study decreased the 
calcium content of hepho in this order DPC>UTC> DTC>UPC (Table 3). This observation was in agreement with the report of Abiodum and Adepeju, (2011) that cooking in boiling water caused a great loss of $\mathrm{Ca}$ $(0.75 \%)$ content in Cowpea, Eijigui et al. (2005) also reported that there was a great loss mineral from red kidney bean by cooking and dehulling. The loss of divalent metals was due to their binding to protein and also to the formation of a phytate-cation protein and leaching of the mineral during treatment (Mittal et al., 2012).

\section{Phosphorus}

The mean phosphorus content of hepho bean was significantly $(p<0.05)$ reduced in all processing methods employed in this study when compared to raw hepho bean seeds. Significances $(p<0.05)$ were also observed in the mean phosphorus values within each processing techniques (Table 3). The mean phosphorus content of raw hepho was $342.27 \mathrm{mg} / 100 \mathrm{~g}$ and this value was lower than the finding of Mubarak (2005), in which the mean phosphorus content of raw mung bean was $391 \mathrm{mg} / 100 \mathrm{~g}$, but this was higher than phosphorus content of underutilized legumes as reported by Ekanayake et al. (2012) that was $291.24 \mathrm{mg} / 100 \mathrm{~g}$. However, the value was comparable with that of chickpea $243.00 \mathrm{mg} / 100 \mathrm{~g}$ as reported by Mittal et al. (2012). The mean Phosphorus content of DTC, UTC, DPC and UPC of hepho seeds were shown in (Table 3). All the processing methods under this study decreased the phosphorus content.DTC, UTC, DPC and UPC samples decreased as shown in (Table 3). The finding was analogous with the report of Abiodum and Adepeju (2011) which state that cooking in boiling water caused reduction of phosphorus by $(0.70 \%)$ in Cowpea and also have similar reduction which observed red kidney bean (Eijigui et al., 2005). The loss of element was due to their binding to protein and also the formation of a phytate-cation protein and leaching of the mineral during treatment (Mittal et al., 2012).

The calcium and phosphorus levels are reasonably distributed in the sample. Phosphorus is always found with calcium in the body both contributing to the blood formation and supportive structure of the body (Ogunlade et al., 2005). Low Ca:P ratio (less than 0.5) facilitates decalcination of calcium in the bone leading to low calcium level in the bones while $\mathrm{Ca} / \mathrm{P}$ ratio above two helps to increase the absorption of calcium in the small intestine (Nieman et al., 1992). The values of $\mathrm{Ca} / \mathrm{P}$ ratio in the present study are far lower than 0.5 .

\section{Iron}

DTC, UTC, DPC and UPC hepho seed mean iron content significantly $(p<0.05)$ varied in hepho iron content, significantly $(p<0.05)$ differences were observed in mean iron content of hepho bean seeds among each tested processing techniques. The UTC and UPC techniques decreased the iron content of hepho (Abiodum and Adepeju, 2011; Mubarak, 2005; Mittal et al., 2012). In Duhan et al. (2000), there was a reduction by cooking which could be as a result of the effect of heat changing in the insoluble chemical species of some trace elements into soluble ones that were extracted in cooking water.

\section{Zinc}

All processing techniques significantly $(p<0.05)$ reduced zinc content. However, non- significantly ( $p>0.05$ ) differences were observed in mean iron content of hepho bean seeds among each tested processing techniques (Table 3). The mean zinc content of raw hepho was 1.70 $\mathrm{mg} / 100 \mathrm{~g}$ (Table 3 ) and the result was higher than the report of Ekanayake et al.(2012) which states that, zinc content of underutilized legumes was found to be 1.37 $\mathrm{mg} / 100 \mathrm{~g}$; however, this is lower than that of mucuna bean $4.1 \mathrm{mg} / 100 \mathrm{~g}$ as reported by Mugendi et al. (2010). The mean Zinc content of raw, DTC, UTC, DPC and UPC, were, 1.40, 1.35, 1.54 and 1.60, respectively (Table 3). UTC and UPC samples decreased the zinc content hepho in the order of UTC $>$ DTC $>$ DPC $>$ UPC.

This might be due to the removal of hull that justifies the presence of elements in hull of hepho. The findings were in agreement with the previous Abiodum and Adepeju (2011) which states that, dehulled cooking reduced the zinc content of Barbara nut by $54.52 \%$.

\section{Conclusion}

The traditional cooking techniques caused an increase in the crude protein contents of Hepho bean seeds than pressure cooking methods which reduced crude fiber and fat contents of Hepho dehulled and undehulled cooked. The total ash generally decreased in all tested treatments. In contrasts, the all tested treatments have no effect on carbohydrate. However, the study indicated that there was a loss of minerals (calcium, phosphorus, iron and zinc) during all tested treatments. All the processing methods employed in this study had shown a great loss of phosphorus and calcium as they bind to anti-nutrients and cooked after de-hulled which mostly affect iron content of Hepho bean.

In general, in one or other way; the processing treatments had significant effect on chemical composition and mineral profile of Hepho bean seeds. The study showed that black climbing bean seeds "hepho" have high protein $(24.63 \%)$ and carbohydrate $(65.85 \%)$ content with nutritionally valuable minerals as comparable with known protein rich plant foods such as soybean and groundnut. Hence, the black climbing bean seeds 
"hepho" is an alternative and cheaper source of protein which contributes to solve the problem of malnutrition; a prevalent problem in developing world especially, Ethiopia.

\section{ACKNOWLEDGMENT}

The author would like to thank Mr. Dirriba Chewaka, Wollega University and Ethiopian Health and Nutrition Research Institute (EHNRI) for the collaborative and advice that made this study possible.

\section{CONFLICT OF INTERESTS}

The author has not declared any conflict of interests.

\section{REFERENCES}

AACC (American Association of Cereal Chemists). (2000). Approve methods of the American association of cereal chemists. American Association of Cereal Chemists, $10^{\text {th }}$ ed. St. Paul, MN.

Abiodum AO, Adeoeju AB (2011). Effect of processing on the chemical, pasting and composition of Banbara Nut (Vigna subterranea L. verdc) flours. Adv. J. Food Sci. 3:224-227.

Akajayeju O, Ajayi OF (2011) .Effects of dehulling on functional and sensory properties of flours from black bean (Phaseolus vulgaris). J. Food Nutr. Sci. 2:344-349.

Akporhonor II, Egwaikhide PA, Eguavoen IO (2006). Effect of sprouting on in vitro digestibility of some locally consumed leguminous seeds. J. Appl. Sci. Environ. Manag. 10(3):55-58.

AOAC (Association of Official Analytical Chemists) (2000). Official methods of analysis. $17^{\text {th }}$ ed. AOAC, Washington, DC.

Aremu MO, Olaofe O, Basu SK, Abdulazeez G, Acharya SN (2010). Processed cranberry bean (Phaseolus coccineus L.) seed flour for the African diet. Can. J. Plant Sci. 90:719-728.

Aremu MO, Olayioye YE, lkokoh PP (2009). Effects of processing on the nutritional quality of kersting's groundnut (Kerstingiella geocorpa L.) seed flours. J. Chem. Soc. Nig. 34(2):140-149.

Aremu MO, Olaofe O, Orjioke CA (2008). Proximate and amino acid composition of bambara groundnut (Vigna subterranea), kersting's groundnut (Kerstingiella geocarpa) and scarlet runner bean (Phaseolus coccineus) protein concentrates. La Rivista Italiana Delle Sostanze Grasse, 85:128-134.

Aremu MO, Olaofe O, Akintayo ET (2006a). A comparative study on the chemical and amino acid composition of some Nigerian underutilized legume flours. Pak. J. Nutr. 5(1):34-38.

Aremu MO, Olaofe O, Akintayo ET (2006b). Compositional evaluation of cowpea (Vigna unguiculata) and scarlet runner bean (Phaselolus coccineus) varieties grown in Nigeria. J. Food Agric. Environ. 4(2):3943.

Aremu MO, Olaofe O, Akintayo ET (2005). Nutritional qualities assessment of the presence of hull in some Nigeria under-utilized legume seeds. Bull. Pure Appl. Sci. 24:47-52.

Audu SS, Aremu MO (2011). Nutritional composition of raw and processed pinto bean (Phaseolus vulgaris L.) grown in Plateau State, Nigeria. J. Food Agric. Environ. 9(3\&4):72-80.

Bultosa G (2007). Common grain nutrient composition and laboratory methods in grain composition analysis. Haramaya University, Ethiopia.

Davis KR (1981). Effects of processing on composition and Tetrahymena relative nutritive value of green and yellow peas lentils and white peas and beans. Cereals Chem. 58:454-560.

Denonck DG (1991). Systematic and morphology. In: A. Van Schoonhoven and $\mathrm{O}$. Voysest, eds. Common beans research for crop improvement. CAB International, Wallingford, UK. pp. 55-118
Derese M (2012). Caning quality evaluation of Haricot Bean ( $P$. vulgaris L.) varieties grown in Ethiopia. M.Sc. Thesis. Chemical Engineering Department, Addis Ababa University, Addis Ababa, Ethiopia.

Duhan A, Khetarpaul N, Bishnoi S (2000). Changes in phytates and $\mathrm{HCl}$ extractability of calcium, phosphorus and iron of soaked, dehulled, cooked and sprouted pigeon pea cultivar (UPAS-120). Plant Food Human Nutr. 57:275-284

Ejigui J, Lsavoie L, Marin J, Desrosiers T (2005). Influence of traditional processing methods on the nutritional composition and anti-nutritional factors of red peanuts (Arachis hypogea) and small red kidney beans (Phaseolus vulgaris). J. BioSci. 5:597-605.

Kylen M, McCready RM (1975). Nutrient in seeds and sprouts of alfalfa lentils, mug beans and soybeans. J. Food Sci. 40:1008-1013

Khalil IA, Khan S (1995). Protein quality of Asian beans and their wild progenitor, Vigna sublobata (Roxb). Food Chem. 52:327-330.

Liener IE (1994). Implications of anti-nutritional components in soya bean foods. Crit. Rev. Food Sci. Nutr. 34:31-67

Mittal R, Nagi H, Sharma P, Sharma S (2012). Effect of processing on chemical composition and anti-nutritional factors in chickpea flour. J. Sci. 2:180-186

Mubarak AE (2005). Nutritional composition and anti-nutritional factors of mung bean seeds (Phaseolus aureus) as affected by some home traditional processes. Food Chem. 89:489-495.

Mugendi JB, Njagi MNE, Kuria NE, Mwasaru MA, Mureifhi JG, Apostolides Z (2010). Effect of processing technique on Mucuna bean. Afr. J. Food Sci. 4:156-166.

Nieman DC, Butterworth DE, Nieman CN (1992). Nutrition. Wm. C Brown Publishers, Dubuque, I. A. P 540.

Nowacki K (1980). Heat stable anti-nutritional factors in leguminous plants. In: Advances in Legume Science, Summefield RJ, Buntong AH (Eds.). Royal Botanical Gardens, Kew, pp. 171-177.

Ogunlade I, Olaofe O, Fadare T (2005). Chemical composition, amino acid and functional properties of Leucaena leucocepha seeds flour. Nig. J. Appl. Sci. 21:7-12.

Omafuvbe BO, Falade OS, Osuntogun BA, Adewusi SRA (2004). Chemical and biochemical changes in African locust bean (Parkia biglibosa) and melon (Citrullus vulgaris) seeds during fermentation to condiments. Pak. J. Nutr. 3(3):140-145.

Onyeike EN, Acheru GN (2002). Chemical composition of selected Nigerian oil seeds and physicochemical properties of the oil extracts. Food Chem. 77:431-437.

Onyeike EN, Olungwe T, Uwakwe AA (1995). Effect of heat treatment and defatting on the proximate composition of some Nigerian local soup thickeners. Food Chem. 53:173-175.

Oshodi AA, Esuoso KO, Akintayo ET (1998). Proximate and amino acid composition of some under-utilized Nigerian legumes flour and protein concentrates. Riv. Ital. Sostanze Grasse. 75:409-412.

Siddhuraju P, Vijayakumari K, Janardhanan K (1996). Chemical composition and protein quality of the little-known legume, velvet bean (Mucuna pruriens L.). J. Agric. Food Chem. 44: 2636-2641.

Shimelis EA, Rakshit SK (2005). Proximate composition and physicochemical properties of improved dry bean (Phaseolus vulgaris L.) varieties grown in Ethiopia. Swiss Soc. Food Sci. Technol. 38:331338.

Fasoyiro FB, Ajibade SR, Omole AJ, Adeniyan ON, Farinde EO (2006). Proximate minerals and anti-nutritional factors of some underutilized legumes in south-western Nigeria. Nutr. Food Sci. 36:18-23

Tadese W, Bekele S (2003). Variation and association of morphological and biochemical characters in grass pea (Lathyrus sativus L.). Euphytical Ethipia 130: 315-324

Temple VJ, Odewumi L, Joseph K (1991). Soybeans and soybeans based diets. Proceedings of the $3^{\text {rd }}$ Regional Workshop on Rural Development, July 31-August 2, 1991, Jos, pp.45-50

Vidivel V, Janardhanen K (2001). Nutritional and anti-nutritional attributes of underutilized legume, Cassia floribunda Car. Food Chem. 73:209-215.

Vidal-Valverde C, Frias J, Valverde S (1993). Changes in the carbohydrate composition of legumes after soaking and cooking. J. Am. Diet Assoc. 93:547-550.

Yagoub AA, Mohammed MA, Baker AAA (2008). Effect of soaking, sprouting and cooking on chemical composition bioavailability of minerals and in vitro protein digestibility of Roselle (Hibiscus 
sabdariffa L.) seed. Pak. J. Nutri.7: 50-56.

Zelalem F (2002). Report on informal survey of major beans disease in Metekel Zone, Pawe Agricultural Research Center. pp. 14-19 (unpublished), Ethiopia. 